\title{
Convergence and Cointegration Analysis under Structural Breaks: Application of Turkey Tourism Markets'
}

Berhan ÇOBAN (https://orcid.org/0000-0002-0080-2025), Department of Statistics, Dokuz Eylül University, Turkey; e-mail: berhan.coban@deu.edu.tr

Esin FİRZAN (https://orcid.org/0000-0002-1333-0864), Department of Statistics, Dokuz Eylül University, Turkey; e-mail: esin.firuzan@deu.edu.tr

\section{Yapısal Kırılmalar Altında Yakınsaklık ve Eşbütünleşme Analizi: Türkiye Turizm Piyasaları Uygulaması ${ }^{2}$}

\begin{abstract}
The purpose of this study is to examine the cointegration structure and to test the convergence hypothesis in Turkey's tourism markets with monthly data over the period 1996-2016. To check the existence of convergence, we used international tourist arrivals to Turkey from each of Turkey's 23 major markets. International tourist arrivals data of Turkey may comprise structural changes and volatility. These attributes may negatively affect the reliability of unit root and cointegration tests outcomes. Ignorance of volatility and breaks leads to decrease in the number of convergent tourism markets. Conventional Dickey Fuller unit root test, recently developed Lagrange multiplier (LM) and Residual Augmented Least Squares (RALS-LM) tests are performed to test the existence of convergence in the tourism market. Gregory Hansen and RALS based cointegration tests are used for checking long run relationship of the tourist arrivals data. The study reveals strong evidence that most of the tourism markets for Turkey are converging. This means that tourism policies and strategies are successful for convergent tourism markets. In addition, there is some long run relationship among the different tourism markets in the presence of structural break and volatility.
\end{abstract}

Keywords $\quad$ : Convergence Hypothesis, Unit Root test, Tourism Markets, Cointegration, Structural Breaks.

JEL Classification Codes : $\quad$ Z32, C22, C58.

Öz

Bu çalışmanın amacı 1996-2016 yılları arasında Türkiye turizm pazarları aylık verilerini kullanarak eşbütünleşme yapısını incelemek ve yakınsaklık hipotezini test etmektir. Yakınsaklık hipotezinin tespiti için 23 önemli ülkeden Türkiye'ye gelen yabancı turist gelişleri verileri

1 This article is the revised and extended version of the paper presented in "Third International Annual Meeting of Sosyoekonomi Society" which was held by Sosyoekonomi Society and CMEE - Center for Market Economics and Entrepreneurship of Hacettepe University and, Faculty of Economics and Administrative Sciences of Hacettepe University, in Ankara/Turkey, on April 28-29, 2017.

2 Bu makale Sosyoekonomi Derneği ile Hacettepe Üniversitesi Piyasa Ekonomisini ve Girişimciliği Geliştirme Merkezi ile Hacettepe Üniversitesi İktisadi ve İdari Bilimler Fakültesi tarafindan Türkiye 'nin Ankara şehrinde, 28-29 Nisan 2017 tarihlerinde düzenlenen “Üçüncü Uluslararası Sosyoekonomi Derneği Yıllık Buluşması”"nda sunulan çalışmanın gözden geçirilmiş ve genişletilmiş halidir. 
kullanılmıştır. Yabancı turist gelişleri verileri yapısal kırılma ve farklı varyanslık içermektedir. Bu özellikler birim kök ve eşbütünleşme test sonuçlarını negatif etkilemektedir. Yapısal kırılma ve farklı varyanslılığın göz ardı edilmesi yakınsak turist gelişlerinin sayısını azaltmaktadır. Yakınsaklık hipotezinin tespiti için geleneksel Dickey Fuller birim kök testi, son yıllarda geliştirilmiş Lagrange multiplier (LM) ve Residual Augmented Least Squares (RALS-LM) testleri kullanılmıştır. Gregory Hansen ve RALS tabanlı eşbütünleşme testleri uzun dönemli denge ilişkisini ortaya çıkarmak için kullanılmıştır. Çalışma, Türkiye için turizm pazarlarının çoğunun yakınsak olduğuna dair güçlü kanıtlar ortaya koymuştur. $\mathrm{Bu}$, turizm politikaları ve stratejilerinin yakınsak turizm piyasaları için başarılı olduğu anlamına gelmektedir. Buna ek olarak, yapısal kırılma ve farklı varyanslılığın varlığında farklı turizm piyasaları arasında eşbütünleşik ilişkiler olduğu tespit edilmiş̧tir.

Anahtar Sözcükler Yakınsaklık Hipotezi, Birim Kök Testi, Turizm Piyasaları, Eşbütünleşme, Yapısal Kırılma.

\section{Introduction}

In the last decades, international tourism has been the one of the largest and fastest growing services industry in the world. The Turkey tourism behaviors have begun to gain momentum in the 2000s in similar to the world tourism movements. Tourism as a sector contributes a substantial proportion to the GDP and the labour force. Tourist spending and whole related activities in sector rise in foreign exchange earnings. Because of this trade, foreign reserves and balance of payments are developed and enhance of the touristic countries. Also, tourism can develop the employment rate in tourism countries. A lot of studies showed that tourism enlargement should have a positive contribution to economic growth. (For detail information see Kim et al., 2006).

The opinion of the tourism market convergence was first implemented by Narayan (2006). After the study of Narayan concerned with Australia's tourism, many similar studies were conducted. There are a lot of causes that to test for the convergence hypothesis in the tourism sector literature. First, if potantial markets are converging, this indications to policy makers that the tourism sector is heading in the accurate. If visitor arrivals from a specific country are converging, it shows that the market is rising in significant and this implies that this market contributes to the accretion in total visitor arrivals.

Second, some countries can desire to target with the aim of diversifying its tourism markets. Convergence analysis can be assistance to policy makers with about information of whether or not visitor arrivals from these smaller markets are converging. Developed countries in terms of tourism, including Turkey, pursue intensive marketing campaigns in different markets. The convergence hypothesis supplies a means of evaluating the success of marketing strategies. In other words, the hypothesis can be beneficial in planning future marketing advertisements.

The convergence hypothesis can be examined using both cointegration and unit root tests. Unit root tests are utilized to test the stationarity of the difference between total international visitor arrivals to the host country $\left(\mathrm{VA}_{\mathrm{t}, \mathrm{H}}\right)$ and host country's visitor arrivals from a specific market $\left(\mathrm{VA}_{\mathrm{i}, \mathrm{t}}\right)$. To check the existence of convergence, we used international 
tourist arrivals to Turkey from each of Turkey's 23 major markets. International tourist arrivals data of Turkey may comprise structural changes and volatility. These attributes may negatively affect the reliability of unit root and cointegration tests outcomes. Ignorance of volatility and breaks leads to decrease in the number of convergent tourism markets.

Conventional Dickey-Fuller unit root test and Lee \& Strazicich' test (LM), recently developed RALS-LM unit root tests with trend-breaks suggested by Meng and Lee (2013) and Lee et al. (2012) tests are performed to test the existence of convergence in the tourism market. Also, we used Engle-Granger (EG), Gregory-Hansen (GH) and RALS cointegration tests while investigating the long run relationship between total visitor arrivals of Turkey and visitor arrivals from a specific market.

\section{Literature Review}

In recent years, convergence literature of tourism markets has developed in many ways. There are a lot of different techniques and samples. The pioneer empirical study of the tourism convergence hypothesis was done by Narayan (2006). In this study research related to Australia's tourism markets with period 1991:01 to 2003:09. Narayan reveals that markets are converging through the Lagrange multiplier (LM) unit root tests. Narayan contributed to the convergence hypothesis literature in 2007. In addition to the previous work, this study contains cointegration tests to find out convergence markets. A study showed that the convergence hypothesis is valid for Fiji's eight major tourism markets over the period 1970 to 2002 .

In addition, Lorde and Moore (2008) searched the convergence hypothesis of the Caribbean district. The study outcomes do not support for convergence. Another remarkable study was done by Lee (2009) for Singapore's tourism markets. Because of analysis ensured proof of the convergence hypothesis. After this study for Singapore tourism markets, Tan and Tan (2013) researched the convergence hypothesis using monthly data for the period 1994 to 2011. The study utilized to invesitgate convergence through both common unit root tests and allowing structural breaks unit root tests.

In reviewing the literature related to Turkey, there are limited studies evaluating the convergence issue in tourism markets. First, Yilanci and Eris (2012) examined the convergence structure in 14 main markets of Turkey using a Fourier stationary test over the monthly period 1996-2010. Study outcomes showed that 10 out of 14 tourism markets are converging.

However, Abbott et al. (2012) ascertained non-convergence results among 20 major tourist source markets of Turkey utilizing the pairwise methodology. Data format are monthly and spaned 1996 and 2009. In parallel, this study, Samirkas and Bahar (2011) promoted Abbott et al. (2012) outcomes. A study using OLS techniques. Lastly, Ozcan and Erdogan (2016) analyze the tourist markets structure. Because of the study, most tourist markets are converging for Turkey source market. 
They used newly developed LM and RALS-LM unit root tests. Thanks to these test, which are taking in to account breaks and non-normality, reveal many convergence markets. According to results, 10 crucial tourism markets from 14 countries of Turkey are performing an additive to the rise in tourist arrivals to Turkey. Also, study find out four markets, which are France, Iran, Italy, and the USA do not convergence. In this study, we extent Ozcan and Erdogan (2016)'s work in terms of a number of tourism markets and cointegration relationship between tourist arrivals and total tourist arrivals of Turkey.

\section{Overview of Turkey's Tourism Market}

Turkey is a very wealthy country in terms of natural beauties, historical places, cuisine variety, and cultural heritage. Turkey tourism is concentrated largely on a diversity of the historical area, and on seaside resorts along its Aegean and Mediterranean coasts. Beach holidays are also fundamental to the Turkish tourism sector. In recent years, Turkey has also become a shining destination for spa and health care tourism and cuisine tourism. In recent years, Turkey has also become a shining destination for spa and health care tourism and cuisine tourism. Particularly since 2000, Turkey has become preferred tourism country in the world.

Figure 1 shows the tourism income and total international visitors to Turkey between 2001 and 2016 and the market share analysis of visitor arrivals in Turkey from its main source markets are presented in Figure 2.

Figure: 1

Tourism Income and Number of Total Visitors between 2001 and 2016

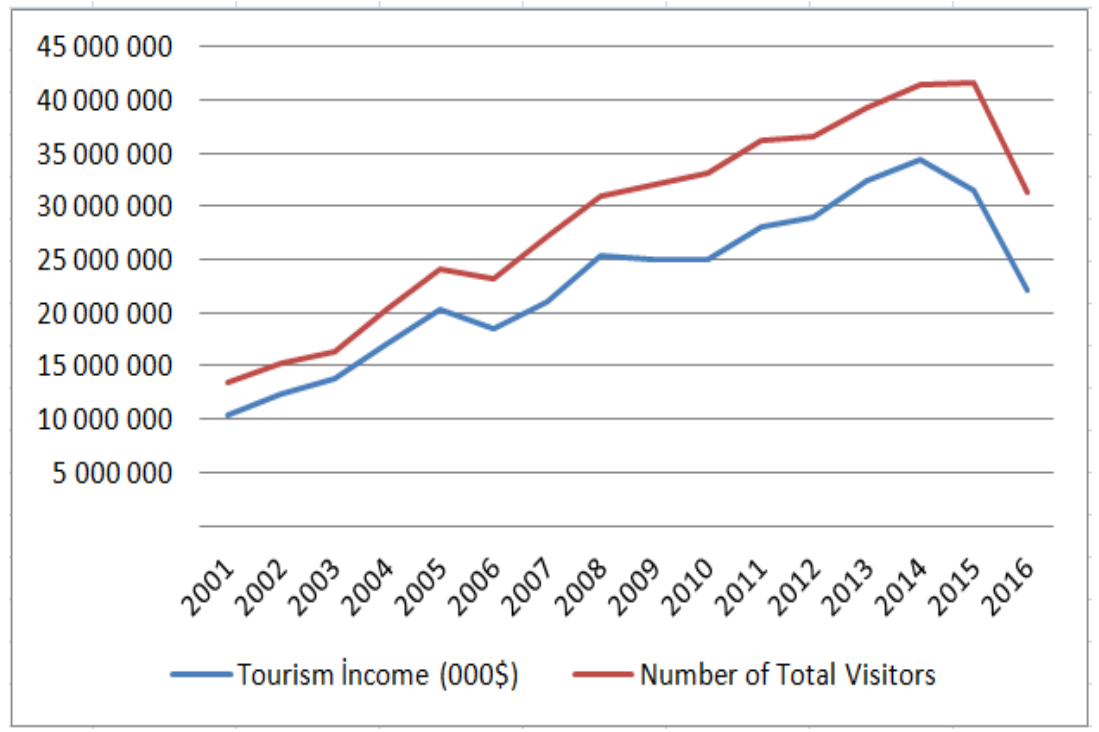




\section{Figure: 2}

\section{Number of Tourist Arrivals of Some Markets}

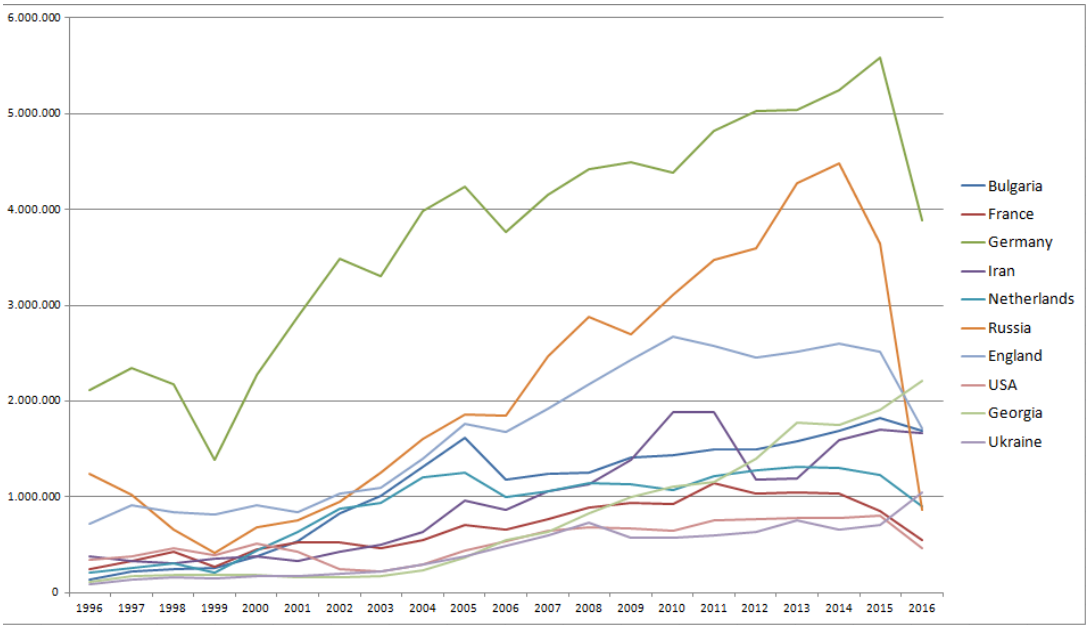

Foreign tourist arrivals incremented remarkably in Turkey between 2001 and 2016, from 8.54 million to 25.35 million. Thanks to these statistics, Turkey a top-10 destination in the world for foreign tourists. In 2015 alone, Turkey fascinated more than 36.456 million foreign visitors. 2015 earnings were US $\$ 31.464$ billion which also made Turkey the top-10 biggest tourist earnings owners in the world (UNWTO, 2013, 2016). For example, Turkey ranked sixth in respect of tourist arrivals in 2015 with 41.617 million. According to the figures, we can express some positive trend and potential structural breaks. Despite these positive developments, terrorist attacks, the Syrian war, and political instability have reduced the number of tourist arrival during 2015 and 2016.

\section{Methodology and Empirical Results}

\subsection{Data and Model}

We studied monthly international tourist arrivals to Turkey from each of Turkey's 23 essential markets over the period January 1996-December 2016. The data we utilize is taken from Turkish Statistical Institute's publication Tourism Statistics. These 23 markets are Austria, Azerbaijan, Belgium, Denmark, France, Germany, Greece, Georgia, Iran, Iraq, Italy, Bulgaria, Netherlands, England, Romania, Sweeden, Switzerland, Kazakhstan, Poland, Saudi Arabia, Ukraine, Russia, and the USA.

The suitable process to test whether the difference between the natural log of total visitor arrivals and visitor arrivals from a specific market is stationary or not, is to use some form of unit root test. If the unit root null hypothesis of a can be rejected, the series is stationary. So, we can have expressed that there is no convergence of tourism markets (Lean \& Smyth, 2008). 
Based on Narayan (2006), we described convergence as below. $Y_{\text {it }}$ is the natural log of the tourist arrivals ratioas shown in equations 1 , which must be stationary for convergence to exist. If Turkey's tourism markets are converging, then the difference between total international visitor arrivals and international visitor arrivals from a source market will approach zero.

$$
Y_{i t}=\ln \left(\frac{\mathrm{VA}_{t, \text { Turkey }}}{\mathrm{VA}_{i t}}\right),
$$

where $\ln$ denotes a natural logarithm, $V A_{t, \text { Turkey }}$ and $V A_{\text {it }}$ are the total international visitor arrivals to Turkey at time $t$ and visitor arrivals to Turkey from country $i$ at time $t$, respectively.

In the time series literature, there are a few unit root tests to investigate stochastic convergence. For example, Augmented Dickey-Fuller (ADF), Phillips-Perron, and KPSS tests. The power of these tests is, however, weakened in the presence of structural breaks and some non-normality features. Consequently, we applied the Lee and Strazicich (2003, 2004) and RALS-LM unit root tests. Because these tests consider breaks and volatility term in the series.

Before doing convergence analysis, we determined the time series component of the data. Series have seasonality, trend, potential structural breaks and some non-normality. First, we remove seasonality effects from series. Some non-seasonal series shown in Figure 3. When the graphs are examined, other compenent are prominent. Therefore, techniques which are investigate the convergence consider these factors. Also, all series contain some volatility component such as ARCH and GARCH model. 
Figure: 3

\section{Log of Tourist Arrivals Ratio for Some Tourism Markets}
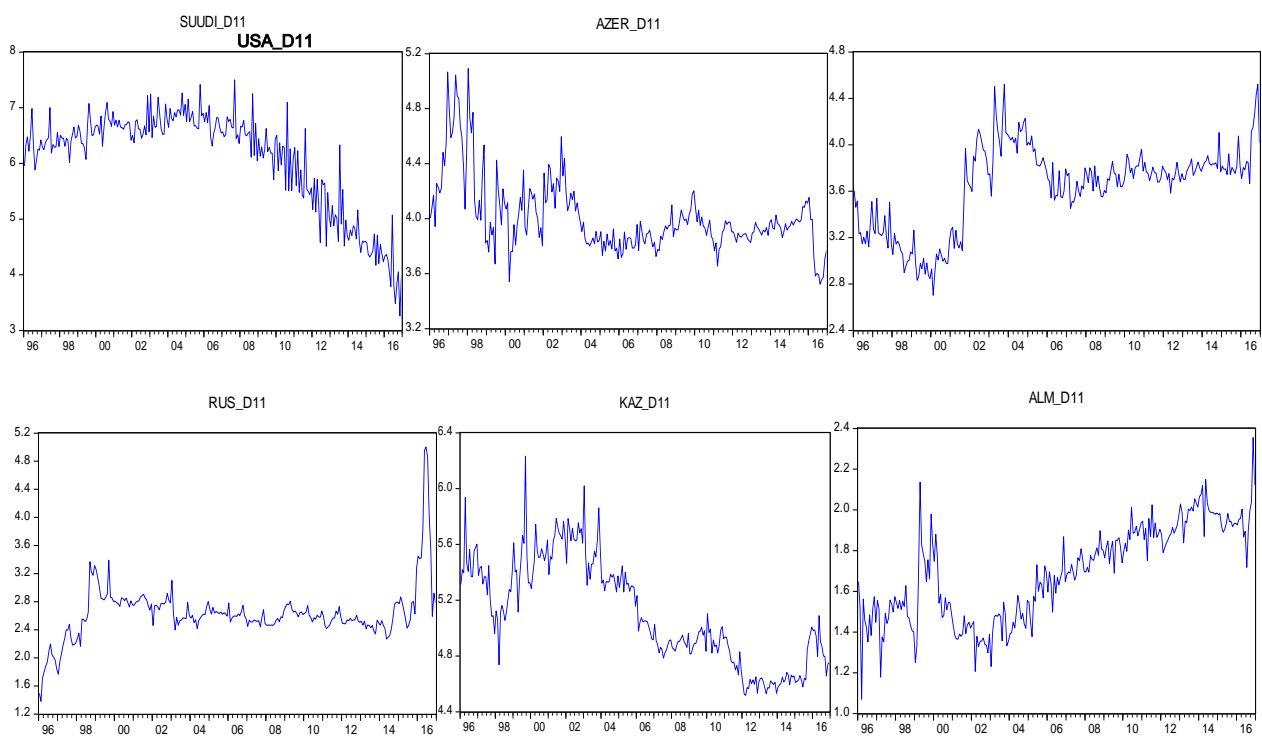

GURC_D11

BULG_D11

IRAN_D11

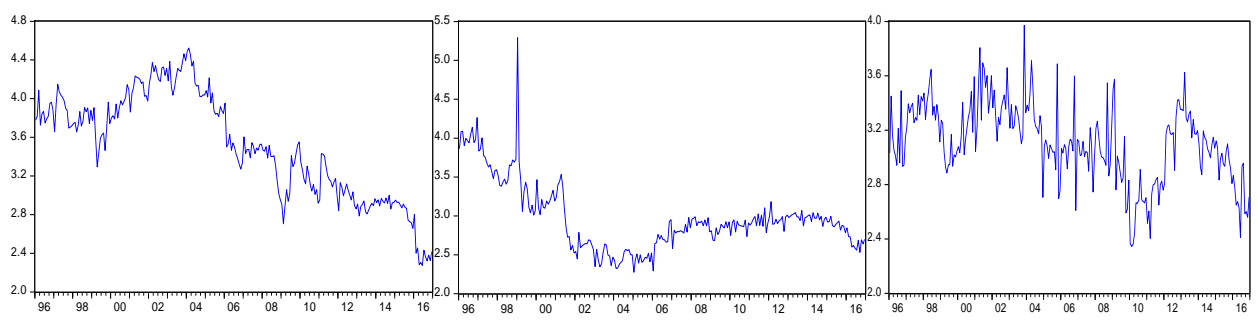

\subsection{Methodology}

Instead of Narayan (2006) approach, we utilize the univariate Lagrange Multiplier (LM) unit root test developed by Lee and Strazicich. The LM univariate test is undertaken to assume no structural breaks, assuming one and two structural breaks. Additionally, we employ the two-step LM and three-step RALS-LM unit root tests developed by Lee et al. (2012) and Meng and Lee (2012). This transformed LM tests do not depend on the break location and allow for trend-breaks under the null hypothesis. In the second test, the authors adopt the new LM tests based on the RALS (residual augmented least squares) regression. These new tests employ the information of non-normal errors that have been ignored in the literature of unit root tests. 
According to the studies of Lee et al. (2012), Meng and Lee (2012) and Meng et al. (2013), the procedures of tests used could be described as follows: First, we can express data generating process (DGP):

$$
y_{t}=\delta^{\prime} Z_{t}+e_{t} e_{t}=\beta e_{t-1}+\varepsilon_{t}
$$

where $Z_{t}=[1, t]$ ' is used in the standard unit root test with a trend function. The unit root null hypothesis is $\beta=1$. Both level-shift and trend-shift can be stated with $Z_{t}=\left[1, t, D_{1 t}, \ldots\right.$, $D_{R t}, D T_{l t}, \ldots, D T_{R t}$ ', where $D_{i t}$ and $D T_{i t}$ are dummy variables showing the locations of the $i$ th level and trend breaks, respectively. $R$ is the maximum number of structural breaks, and $T_{B i}$ is the location of the $i$ th structural break in equation 4 .

Following the LM (score) principle, the unit root test statistic is then obtained from the following regression equation:

$$
\Delta y_{t}=\delta^{\prime} \Delta Z_{t}+\phi \tilde{S}_{t-1}+e_{t}
$$

where $\widetilde{S}_{t}$ is the LM detrended $y_{t}$ series, here, $\widetilde{\delta}$ is the coefficient vector obtained in the regression of $\Delta y_{t}$ on $\Delta Z_{t}$ where the first difference of $y_{t}$ and $Z_{t}$ are used.

Meng et al. consider a simple transformation which can make the unit root test statistic dependency free on the break location. The following transformation can exract the dependency on the break location parameter:

$$
\tilde{S}_{t}^{*}= \begin{cases}\frac{T}{T_{B 1}} \tilde{S}_{t} & \text { for } t \leq T_{B 1} \\ \frac{T}{T_{B 2}-T_{B 1}} \tilde{S}_{t} & \text { for } T_{B 1}<t \leq T_{B 2} \\ \mathrm{M} & \text { for } T_{B R}<t \leq T \\ \frac{T}{T-T_{B R}} \tilde{S}_{t} & \text { f }\end{cases}
$$

where $\widetilde{S}_{t}^{*}$ is the transformed series. We then replace $\widetilde{S}_{t-1}$ in the testing regression (3) with $\widetilde{S}_{t-1}^{*}$ such that we have a new testing regression $\Delta y_{t}=\delta^{\prime} \Delta Z_{t}+\phi \widetilde{S}_{t-1}^{*}+e_{t}$. To develop the efficient of the LM test, authors adopted the "residual augmented least squares" (RALS) method as in Im, Lee, and Tieslau (2014) to employ the information on non-normal disturbance term. 
To capture the information of non-normal errors, they involve the second and third moments of square of error term into the equation 3 . This condition improves the efficiency of the estimator of dependency parameter when the error terms are not symmetric.

The transformed RALS-LM test statistic with trend-breaks is obtained from the regression

$$
\Delta y_{t}=\delta^{\prime} \Delta Z_{t}+\phi \tilde{S}_{t-1}^{*}+\gamma^{\prime} \hat{w}_{t}+u_{t}
$$

One may relate equation (3) to this regression with $e_{t}=\gamma^{\prime} \hat{w}_{t}+u_{t}$ where $\hat{w}_{t}$ is uncorrelated with $u_{t}$, as proved in $\mathrm{Li}$ and Lee (2015). Authors take $E\left(u_{t}^{2}\right)=E\left(e_{t}^{2}\right)-\left[E\left(e_{t} u_{t}\right)\right]^{2} / E\left(\hat{w}_{t}^{2}\right) \quad$ since $\quad \gamma=E\left(\hat{w}_{t} e_{t}\right) / E\left(\hat{w}_{t}^{2}\right) \quad$ Thus, $E\left(e_{t}^{2}\right)<E\left(u_{t}^{2}\right)$ implying that the variance of the error term in (5) is smaller than that in (3). This result will provide the asymptotic efficiency gain (thus, increase in power of the test) with non-normal errors.

The asymptotic distribution of the new test can be given as

$$
\tau_{R A L S-L M}^{*} \rightarrow \rho \tau_{L M}^{*}+\sqrt{1-\rho^{2} Z}
$$

where $\rho$ reflects the relative ratio of the variances of two error terms such that $\left.\rho^{2}=E\left(u_{t}^{2}\right) / E\left(e_{t}^{2}\right)\right)$ Meng et al. (2012) show that the asymptotic distribution of the RALS-LM test without breaks ( $\tau_{\text {RALS-LM }}$ ) is given as $\tau_{R A L S-L M} \rightarrow \rho \tau_{L M}+\sqrt{1-\rho^{2} Z}$. The distribution is same as this state when trend-shifts are allowed in the LM test, however it rely on the location of breaks without the transformation in (4). Through this transformation asymptotic distribution of the RALS-LM test statistic does not depend on parameter location.

We extend the analysis of convergence to a test for cointegration, discussing that if total visitor arrivals are cointegrated with visitor arrivals from a particular origin market then this is also equal to convergence of markets. To cointegration analysis, we use RALS test which is newly developed tests by Pierdzioch C. et al. (2015). 


\subsection{RALS Cointegration Test}

Following the pioneering work of Engle and Granger (1987), two series are cointegrated when the residuals of a linear regression of one series onto the other are stationary. Ordinary least squares (OLS) regression equation

$$
\begin{aligned}
& y_{t}=\beta_{o}+\beta_{1} x_{t}+u_{t} \\
& \Delta u_{t}=\rho_{1} u_{t-1}+\varepsilon_{t}
\end{aligned}
$$

Im and Schmidt (2008) indicate that deviations from normality can be taken into account by augmenting Eq.(6) with two new regressors that correct for skewness and excess kurtosis. As Taylor and Peel (1998), Pierdzioch C. et Al. (2015) characterize $\hat{w}_{t}=\left(\hat{\varepsilon}_{t}^{3}-3 \hat{\sigma}^{2} \hat{\varepsilon}_{t}, \hat{\varepsilon}_{t}^{2}-\hat{\sigma}^{2}\right)^{\prime}$, and transform Eq.(6) into the following RALS regression equation.

$$
\Delta u_{t}=\rho_{1}^{*} u_{t-1}+\gamma^{\prime} \hat{w}_{t}+\varepsilon_{t}
$$

where $\rho_{1}^{*}$ is the RALS cointegration parameter. The variance of $\rho_{1}^{*}$ is calculated as

$$
\hat{V}\left(\rho_{1}^{*}\right)=\tilde{\sigma}_{A}^{2}\left(\tilde{x}^{\prime}\left(I_{T}-\tilde{w}\left(\widetilde{w}^{\prime} \tilde{w}\right)^{-1} \widetilde{w}^{\prime}\right) \tilde{x}\right)^{-1}
$$

where $I_{T}$ denotes an identity matrix, for detail information of about other parameters see Pierdzioch et al. $(2015,134)$. The RALS statistic for null of no cointegration is computed as $C R_{R A}=\hat{\rho}_{1}^{*} / \sqrt{\hat{V}\left(\hat{\rho}_{1}^{*}\right)}$.

The RALS test is a beneficial technique for studying the cointegration relation between the time series. RALS methodology accounts for the effects of nonnormal error and breaks on the cointegration relation using a simple modification of the common EngleGranger test.

\subsection{Empirical Results}

Initially, to obtain empirical analysis results by investigating the LM and ADF tests without any breaks and defining volatility structure, we can state all series have volatility component with different parameters. 
Table: 1

The Results of No Break Unit Root Tests and Volatility

\begin{tabular}{|c|c|c|c|}
\hline Country & $\mathrm{ADF}$ & LM & Volatility Model \\
\hline USA & -1.392 & -1.505 & $\mathrm{ARCH}(1)$ \\
\hline Germany & -2.825 & -2.428 & $\operatorname{GARCH}(1,1)$ \\
\hline Austria & -3.039 & $-3.838(a)$ & $\operatorname{GARCH}(2,1)$ \\
\hline Azerbaijan & $-3.182(c)$ & $-2.800(\mathrm{c})$ & $\operatorname{GARCH}(1,2)$ \\
\hline Belgium & -1.617 & -0.733 & $\operatorname{GARCH}(2,3)$ \\
\hline Bulgaria & -2.506 & -1.922 & $\operatorname{GARCH}(1,1)$ \\
\hline Denmark & $-3.623(b)$ & $-3.625(b)$ & $\operatorname{GARCH}(2,1)$ \\
\hline France & -2.651 & $-2.894(\mathrm{c})$ & $\operatorname{GARCH}(1,2)$ \\
\hline Georgia & -2.650 & -2.442 & $\operatorname{GARCH}(1,1)$ \\
\hline Netherlands & -1.755 & -1.461 & $\operatorname{GARCH}(2,2)$ \\
\hline England & -6.106 & $-7.536(a)$ & $\operatorname{GARCH}(2,3)$ \\
\hline Iraq & -2.270 & -2.207 & $\operatorname{GARC}(1,2)$ \\
\hline Iran & -2.725 & -3.059 (b) & $\operatorname{GARCH}(2,3)$ \\
\hline Sweden & $-3.280(c)$ & $-3.350(b)$ & $\mathrm{ARCH}(1)$ \\
\hline Switzerland & -2.713 & -2.712 & $\operatorname{GARCH}(3,1)$ \\
\hline Italy & -2.126 & -2.585 & $\mathrm{ARCH}(1)$ \\
\hline Kazakhstan & -2.042 & -1.636 & GARC $(1,2)$ \\
\hline Poland & -3.004 & $-3.108(b)$ & $\mathrm{ARCH}(2)$ \\
\hline Romania & -1.386 & -1.663 & $\operatorname{GARC}(1,2)$ \\
\hline Russia & $-4.583(a)$ & $-3.450(b)$ & $\operatorname{GARC}(2,2)$ \\
\hline Saudi Arabia & -0.008 & 0.172 & $\mathrm{ARCH}(1)$ \\
\hline Ukraine & $-4.623(a)$ & -2.226 & $\operatorname{GARC}(1,2)$ \\
\hline Greece & -2.963 & $-3.668(a)$ & $\operatorname{GARC}(1,2)$ \\
\hline \multicolumn{4}{|l|}{ critical values } \\
\hline (a) $1 \%$ & -3.996 & -3.63 & \\
\hline (b) $5 \%$ & -3.428 & -3.06 & \\
\hline (c) $10 \%$ & -3.138 & -2.77 & \\
\hline
\end{tabular}

According to Table 1 ADF tests shows Azerbaijan, Denmark, Sweeden, Russia, and Ukraine appear to converge. LM test results are supported to ADF results. 
Table: 2

The Results of One Break LM and RALS-LM Unit Root Tests

\begin{tabular}{|c|c|c|c|c|}
\hline Country & $\mathrm{t* \textrm {LM }}$ & TB-1 & t*RALS-LM & $\underline{\text { TB-1 }}$ \\
\hline USA & -2.536 & $2001 / 10$ & -4.267 (b) & $2000 / 04$ \\
\hline Germany & -3.883 & $2005 / 06$ & $-5.970(a)$ & $2005 / 06$ \\
\hline Austria & -4.945 (b) & 1999/03 & $-6.900(a)$ & 2013/07 \\
\hline Azerbaijan & -4.331 & 1998/06 & -4.730 (a) & $1998 / 05$ \\
\hline Belgium & -3.147 & $2006 / 03$ & $-6.515(a)$ & $2010 / 03$ \\
\hline Bulgaria & -4.18 & $2006 / 01$ & -4.082 & $2005 / 12$ \\
\hline Denmark & -6.427 (a) & $2000 / 08$ & -4.024 & $2006 / 04$ \\
\hline France & -4.077 & $2012 / 10$ & $-4.476(b)$ & $2012 / 01$ \\
\hline Georgia & -4.119 & $2005 / 03$ & -3.055 & $2005 / 02$ \\
\hline Netherlands & -3.462 & 2002/04 & -2.792 & $2005 / 03$ \\
\hline England & -8.228 (a) & 2005/04 & -5.664 (a) & $2005 / 04$ \\
\hline Iraq & -2.207 & 2003/07 & -5.550 (a) & 2003/07 \\
\hline Iran & -3.707 & $2005 / 10$ & -3.343 & $2004 / 12$ \\
\hline Sweden & -4.278 & 2003/01 & -6.049 (a) & $1999 / 10$ \\
\hline Switzerland & -3.766 & $2002 / 07$ & -2.370 & 1999/09 \\
\hline Italy & -3.527 & 1998/11 & -3.131 & $2007 / 04$ \\
\hline Kazakhstan & -3.024 & 2003/01 & -3.691 & $2012 / 12$ \\
\hline Poland & -4.443 & $2010 / 05$ & -3.078 & $2001 / 11$ \\
\hline Romania & -3.231 & $2000 / 01$ & -4.914 (a) & $2000 / 02$ \\
\hline Russia & $-5.048(b)$ & 1999/09 & $-5.779(a)$ & $1999 / 12$ \\
\hline Saudi Arabia & -4.891 (b) & 2008/08 & -5.203 (a) & $2008 / 10$ \\
\hline Ukraine & $-4.458(b)$ & $1998 / 03$ & $-5.251(\mathrm{a})$ & 1999/09 \\
\hline Greece & -4.817 (b) & $2002 / 12$ & $-6.917(a)$ & $2005 / 01$ \\
\hline \multicolumn{5}{|l|}{ critical values } \\
\hline (a) $1 \%$ & -5.11 & & -4.723 & \\
\hline (b) $5 \%$ & -4.5 & & -4.205 & \\
\hline (c) $10 \%$ & -4.21 & & -3.937 & \\
\hline
\end{tabular}

When we investigate the one break case of convergence hypothesis, it can be expressed that 8 tourist arrivals ratio is stationary (convergence) in 23 countries under the LM test whereas 14 out of 23 countries under RALS-LM test. In this result, it shows that breaks impact on the results of the tests. If structural breaks are disregarded, the tourism policies of Turkey in primary tourist source markets look inefficient and unprosperous. 
Table: 3

The Results of Two Breaks LM and RALS-LM Unit Root Tests

\begin{tabular}{|c|c|c|c|c|c|c|c|}
\hline Country & $\mathrm{t} * \mathrm{LM}$ & TB-1 & TB-2 & t*RALS-LM & TB-1 & TB-2 & Convergence status \\
\hline USA & $\overline{-4.742}$ & $\overline{2001 / 07}$ & $\overline{2006 / 03}$ & -3.617 & $\overline{2001 / 07}$ & $\overline{2001 / 11}$ & Not Convergence \\
\hline Germany & -4.932 & 1999/04 & $2001 / 04$ & $-5.466(a)$ & $1999 / 01$ & $1999 / 05$ & Convergence \\
\hline Austria & $-6.129(a)$ & 1998/04 & $2000 / 04$ & $-8.746(a)$ & $1999 / 04$ & $2013 / 07$ & Convergence \\
\hline Azerbaijan & $-5.714(b)$ & $1998 / 05$ & $2004 / 02$ & $-9.205(a)$ & $1998 / 03$ & $2000 / 12$ & Convergence \\
\hline Belgium & -4.572 & $1999 / 08$ & $2006 / 03$ & $-9.408(a)$ & $1998 / 02$ & $2006 / 03$ & Convergence \\
\hline Bulgaria & $-5.424(b)$ & $2001 / 08$ & $2006 / 02$ & $-7.153(a)$ & $1998 / 12$ & $1999 / 03$ & Convergence \\
\hline Denmark & $-7.115(a)$ & $1998 / 06$ & $2008 / 03$ & $-8.701(a)$ & $2006 / 03$ & $2006 / 06$ & Convergence \\
\hline France & -5.265 & $2003 / 01$ & $2011 / 03$ & -3.535 & $1999 / 07$ & $1999 / 10$ & Not Convergence \\
\hline Georgia & $-6.434(a)$ & $2000 / 11$ & $2012 / 01$ & $-6.611(a)$ & $1999 / 08$ & $2001 / 01$ & Convergence \\
\hline Netherlands & -4.920 & $2000 / 01$ & $2005 / 02$ & -3.877 & $1999 / 01$ & $1999 / 05$ & Not Convergence \\
\hline England & -9.699 (a) & $2001 / 03$ & $2008 / 12$ & $-8.164(a)$ & $2000 / 10$ & $2005 / 05$ & Convergence \\
\hline Iraq & $-6.351(a)$ & $1999 / 07$ & $2003 / 08$ & $-6.941(a)$ & $1999 / 06$ & $1999 / 09$ & Convergence \\
\hline Iran & $-5.850(a)$ & $2005 / 09$ & $2012 / 02$ & -3.671 & $2005 / 09$ & $2005 / 12$ & Not Convergence \\
\hline Sweden & $-5.598(b)$ & 1999/08 & $2014 / 10$ & $-6.971(a)$ & 1999/09 & $2003 / 01$ & Convergence \\
\hline Switzerland & $-5.7(b)$ & $1999 / 10$ & $2005 / 08$ & -4.095 & $1999 / 08$ & $2005 / 05$ & Convergence \\
\hline Italy & -5.029 & 2006/07 & $2014 / 11$ & -3.51 & 1998/09 & $1999 / 01$ & Not Convergence \\
\hline Kazakhstan & -4.137 & $2000 / 04$ & $2006 / 02$ & $-4.384(b)$ & $1999 / 08$ & $1999 / 11$ & Convergence \\
\hline Poland & $-5.870(a)$ & $2003 / 02$ & $2009 / 06$ & -4.032 & $1998 / 03$ & $1998 / 06$ & Convergence \\
\hline Romania & -4.643 & $1999 / 01$ & $2001 / 01$ & -9.999 (a) & $2004 / 02$ & $2004 / 05$ & Convergence \\
\hline Russia & $-6.898(a)$ & $1998 / 07$ & $2014 / 06$ & $-7.354(a)$ & $1999 / 08$ & $2003 / 01$ & Convergence \\
\hline Saudi Arabia & $-7.268(a)$ & $2008 / 08$ & $2011 / 08$ & $-8.920(a)$ & $2007 / 08$ & $2011 / 08$ & Convergence \\
\hline Ukraine & $-5.343(b)$ & 1998/09 & $2014 / 08$ & $-6.955(a)$ & $1999 / 09$ & $2003 / 02$ & Convergence \\
\hline Greece & $-6.363(a)$ & $2002 / 08$ & $2007 / 01$ & $-4.467(b)$ & $2001 / 09$ & $2001 / 12$ & Convergence \\
\hline \multicolumn{8}{|l|}{ critical values } \\
\hline (a) $1 \%$ & -5.823 & & & -4.723 & & & \\
\hline (b) $5 \%$ & -5.286 & & & -4.205 & & & \\
\hline (c) $10 \%$ & -4.989 & & & -3.937 & & & \\
\hline
\end{tabular}

Finally, we apply the two-step LM and three-step RALS-LM unit root tests improved by Lee et al. (2012) and Meng and Lee (2012), respectively, for two break case. Results demonstrated that most of the tourism markets are converging except for USA, France, Netherlands, Iran, and Italy. The results of unit root tests of the log of the tourist arrivals ratio allowance of one structural break reveal that seven countries for the LM test and fourteen countries for the RALS-LM. However, the results of unit root tests indicate the null hypothesis of a unit root are rejected for seven countries using the LM test and fourteen countries with the RALS-LM test. The results of unit root tests with an allowance of two structural breaks show that under the LM test fifteen countries reject the null hypothesis of a unit root while under the RALS-LM test sixteen countries reject the null hypothesis. As shown in tables, the number of stationary outcames decreases when the breaks and volatility are rule out. Overleap of structural breaks cause rises in the number of countries that have non-convergent tourism markets. 


\section{Table: 4}

Cointegration Tests Result with and without Break

\begin{tabular}{|c|c|c|c|c|c|c|c|}
\hline \multirow[t]{2}{*}{ Country } & \multicolumn{4}{|c|}{ Gregory-Hansen } & \multirow{2}{*}{$\begin{array}{l}\text { EG-adf } \\
\text { Test stat }\end{array}$} & \multirow{2}{*}{$\begin{array}{l}\text { RALS } \\
\text { Test stat }\end{array}$} & \multirow{2}{*}{$\begin{array}{c}\text { Efficiency } \\
\text { Gain } \%\end{array}$} \\
\hline & Model & Lag & Test stat & Break date & & & \\
\hline USA & $\mathrm{C}$ & 1 & -8.573 & $2006 / 9$ & -6.010 & -5.832 & 0.680 \\
\hline Germany & $\mathrm{C} / \mathrm{T}$ & 1 & -12.95 & $1999 / 2$ & -7.144 & -6.146 & 0.600 \\
\hline Austria & $\mathrm{C} / \mathrm{S}$ & 1 & -7.673 & $2012 / 10$ & -9.018 & -9.326 & 0.943 \\
\hline Azerbaijan & $\mathrm{C}$ & 1 & -8.371 & $2006 / 8$ & -5.742 & -5.850 & 0.972 \\
\hline Belgium & $\mathrm{C}$ & 1 & -9.057 & $2002 / 9$ & -6.751 & -7.378 & 0.940 \\
\hline Bulgaria & $\mathrm{C} / \mathrm{S}$ & 1 & -8.434 & $2013 / 10$ & -7.123 & -6.992 & 0.961 \\
\hline Denmark & $\mathrm{C} / \mathrm{S}$ & 1 & -6.333 & $2006 / 8$ & -6.939 & -6.887 & 0.863 \\
\hline France & $\mathrm{C} / \mathrm{T}$ & 1 & -9.978 & $2003 / 8$ & -4.607 & -4.744 & 0.872 \\
\hline Georgia & $\mathrm{C} / \mathrm{S}$ & 0 & -8.221 & $2002 / 8$ & -5.647 & -6.028 & 0.957 \\
\hline Netherlands & $\mathrm{C} / \mathrm{S}$ & 0 & -10.76 & $2003 / 5$ & -7.634 & -7.714 & 0.896 \\
\hline England & $\mathrm{C} / \mathrm{S}$ & 2 & -11.13 & $2005 / 12$ & -10.02 & -9.073 & 0.896 \\
\hline Iraq & $\mathrm{C}$ & 0 & -7.766 & $2006 / 5$ & -6.012 & -6.078 & 0.963 \\
\hline Iran & $\mathrm{C}$ & 2 & -9.281 & $2001 / 9$ & -4.903 & -4.652 & 0.956 \\
\hline Sweden & $\mathrm{C} / \mathrm{S}$ & 0 & -6.037 & $2011 / 11$ & -4.505 & -4.512 & 0.918 \\
\hline Switzerland & $\mathrm{C}$ & 0 & -7.458 & $2003 / 3$ & -4.341 & -5.545 & 0.861 \\
\hline Italy & $\mathrm{C} / \mathrm{T}$ & 0 & -8.099 & 1999/39 & -7.520 & -8.341 & 0.861 \\
\hline Kazakhistan & $\mathrm{C} / \mathrm{T}$ & 2 & -10.95 & $2003 / 8$ & -4.558 & -5.636 & 0.683 \\
\hline Poland & $\mathrm{C} / \mathrm{T}$ & 1 & -8.708 & $2012 / 2$ & -8.009 & -8.157 & 0.948 \\
\hline Romania & $\mathrm{C} / \mathrm{T}$ & 1 & -6.898 & $2008 / 11$ & -6.156 & -6.908 & 0.904 \\
\hline Russia & $\mathrm{C} / \mathrm{T}$ & 0 & -6.336 & $2003 / 9$ & -5.446 & -5.149 & 0.913 \\
\hline Saudi Arabia & $\mathrm{C} / \mathrm{T}$ & 1 & -8.495 & $2010 / 1$ & -5.479 & -5.697 & 0.959 \\
\hline Ukraine & $\mathrm{C} / \mathrm{S}$ & 0 & -5.582 & $2003 / 9$ & -4.976 & -6.905 & 0.755 \\
\hline Greece & $\mathrm{C} / \mathrm{S}$ & 0 & -8.950 & $2011 / 11$ & -6.678 & -6.620 & 0.966 \\
\hline \multicolumn{8}{|l|}{ Critical values } \\
\hline (a) $1 \%$ & & & -5.47 & & -3.15 & -3.12 & \\
\hline (b) $5 \%$ & & & -4.99 & & -3.45 & -3.41 & \\
\hline (c) $10 \%$ & & & -4.72 & & -4.01 & -3.97 & \\
\hline
\end{tabular}

For substantiality, we further perform the cointegration test to reseach the convergence hypothesis in this study. The RALS approach of Pierdzioch, Risse and Rohloff (2016) and Gregory Hansen tests used to check cointegration in visitor arrivals. When the analysis results are examined all tourism, market are cointegrated with total tourist arrival of Turkey. On the other hand, RALS cointegration test calculates efficiency gain. This value indicates the reduction of variance for cointegration parameter. This value gives information about heteroscedasticity or nonnormality. According to Table 4, we can express series of visitor arrivals of USA, Germany, Kazakhstan, and Ukraine are heteroscedasticity or volatility term.

Results of our empirical study contrast with Abbott et al. (2012)' outcomes; however, results are coherent with Yilanci and Eris (2012) and Ozcan and Erdogan (2016).

\section{Conclusion and Policy Implications}

The implication of this finding is that most of Turkey's 23 major markets are contributing to the increase in tourist arrivals in Turkey. Generally, our empirical results show that most tourism markets of Turkey are convergent with two structural breaks. These results are consistent with cointegration tests. Other than these results, tourism markets of USA, France, Netherland, Iran, and Italy does not provide convergence hypothesis.

Concerning the break dates, for the USA, its first and second break around the 9/11 terrorist attacks. The Izmit earthquake on 17 August 1999 effects the tourist arrivals from France, as well as Georgia, Iraq, Kazakhstan, Russia, and Ukraine. About Iran, the 
presidential election in June 2005, have significant effects on tourist behavior from Iran. Due to the introduction of the euro as an accounting currency to the world financial markets on 1 January 1999, tourist arrivals from Netherlands and Italy are affected their first and second break. Additionally, the Kosova War affected tourist arrivals from Bulgaria. Depend on the above significant break dates, we can explain that political, social, natural and economic crises have a vital influence on Turkey's tourism industries.

Turkey could not have a sufficient tourism policy for these five non-convergent markets. On the other hand, relatively new markets which are Kazakhstan, Saudi Arabia, Ukraine, and Azerbaijan are convergent. This proves that marketing strategies of these countries are effective. In other words, convergence and cointegration results indicate that a lot of tourism source markets are convergent in Turkey. Marketing strategies and advertising actions attracting visitors from these convergence markets. Marketing strategies should be developed for relatively new tourism markets and nonconvergent markets.

\section{References}

Abbott, A. \& G. Vita \& L. Altinay (2012), "Revisiting the convergence hypothesis for tourism markets: Evidence from Turkey using the pairwise approach", Tourism Management, 33, 537-544.

Gregory, A.W. \& B.E. Hansen (1996), "Residual-based tests for cointegration in models with regime shifts", Journal of Econometrics, 70, 99-126.

Im, K.S. \& P. Schmidt (2008), "More efficient estimation under non-normality when higher moments do not depend on the regressors using residual augmented least squares", J.Econ., 144, 219-233.

Im, K.S. \& J. Lee \& M. Tieslau (2014), "More powerful unit root tests with non-normal errors", in: R.C. Sickles \& W.C. Horrace (eds.), Festschrift in honor of Peter Schmidt: Econometric methods and applications, New York: Springer, 315-342.

Kim, H.J. \& M.H. Chen \& S.C. Jang (2006), "Tourism expansion and economic development: The case of Taiwan", Tourism Management, 27, 925-933.

Lean, H.H. \& R. Smyth (2008), “Are Malaysia's tourism markets converging? Evidence from univariate and panel unit root tests with structural breaks", Tourism Economics, 14, 97 112.

Lee, C.G. (2009), "The convergence hypothesis for tourism markets: Evidence from Singapore”, Tourism Economics, 15, 875-881.

Lee, J. \& M.C. Strazicich (2004), "Minimum LM unit root test with one structural break", Working Paper No. 0417, Boone: Appalachian State University.

Lee, J. \& M.C. Strazicich \& M. Meng (2012), "Two-step LM unit root tests with trend-breaks", Journal of Statistical and Econometric Methods, 1, 81-107.

Li, J. \& J. Lee (2015), "Improved Autoregressive Forecasts in the Presence of Non-Normal Errors", Journal of Statistical Computation and Simulation, 85(14), 2936-2952.

Lorde, T. \& W. Moore (2008), "Co-movement in tourist arrivals in the Caribbean", Tourism Economics, 3, 631-643.

Meng, M. \& J.E. Payne \& J. Lee (2013), "Convergence in per capita energy use among OECD countries”, Energy Economics, 36, 536-545. 
Meng, M. \& J. Lee (2012), "More powerful LM unit root tests with trend-breaks in the presence of non-normal errors", Working Paper, University of Alabama.

Narayan, P.K. (2006), “Are Australia's tourism markets converging?”, Applied Economics, 38, 1153 1162.

Narayan, P.K. (2007), “Testing convergence of Fiji's tourism markets", Pacific Economic Review, $12,651-663$.

Ozcan, B. \& S. Erdogan (2015), “Are Turkey's tourism markets converging? Evidence from the two step LM and three-step RALS-LM unit root tests”, Current Issues in Tourism., 1-18.

Pierdzioch, C. \& M. Risse \& S. Rohloff (2015), "Cointegration of the prices of gold and silver: RALS- based evidence", Finance Research Letters, 15, 133-137.

Samirkas, M. \& O. Bahar (2011), "Turizm Sektörünün Bölgelerarası Gelişmişlik Farklılıklarını Gidermedeki Etkisi: Yakınsama Modeli”, Finans Politik \& Ekonomik Yorumlar, 48(557), 70-85.

Tan, S.H. \& S.K. Tan (2013), “Are Singapore's tourism markets converging with structural breaks?”, Tourism Economics, 19, 209-216.

Tang, C.F. (2011), “Old wine in new bottles: Are Malaysia's tourism markets converging?", Asia Pacific Journal of Tourism Research, 16, 263-272.

Taylor M.P. \& D.A. Peel (1998), "Periodically collapsing stock price bubbles: a robust test", Econ. Lett., 61, 221-228.

Turkish Statistical Institute, (2017), Tourism Statistics, <http://www.turkstat.gov.tr/>, 23.02.2017.

UNWTO (2013 \& 2016), Tourism Highlights, World Tourism Organization: Madrid.

Yilanci, V. \& Z.A. Eris (2012), “Are tourism markets of Turkey converging or not? A Fourier stationary analysis", Anatolia: An International Journal of Tourism and Hospitality Research, 23, 207-216. 